санною, не системною, различнаго напряженія; тањь и амнезія тағже бываеть частичною, отрывочног, безсвязною и то полною, то в' состияніи полусознательномъ. Подобно анэстевіи, и амнезія бываеть преимущественно временною и легко исправляется. Что это состояніе амневіи проходитъ и не переходтть в'ь слабоуміе-авторь даеть объясненіе въ томь направленіи, что при амнезіп бываеть не полное разрушеніе образовъ, а тольво иребываніе џхъ въ латентном', подсознательномь состоянік. Проф. П. И. Ковалевскій

Dr, Ch. de Montet und dr. W. Skop. Myasthenia gravis und Maskelatrophie. Monatsschrift f. Psychiatrie und Neurologie 7. I908.

Описанъ случай міастеніи съ р'вяо выраженной атроборіей всей мусгулатуры и явно выраженной міастенической реакціей. Случай-единственный въ литератур' по продолжительности теченія; авторы считають атрофою мускулатуры, входящей въ спматомокомплевсп міастеніп; не наблюдалось это явленіе потому, что больные быстро умирали. Причвной міастеніи авторы считають интоксивацію.

\title{
A. ПІІоломовичг.
}

А. Дылева. Мыпечная спла прш прожательномь параличь. Sur la force musculaire dans la Maladie de Parkinson. Изъ отчетовъ Неврологич. Об-ва въ Париж отдьленія проф. Dejerine вь Сальпетріерђ.

На освованіи двухъ случ. П. б. авторь приходить въ выводу, тто ақтиввыя движенія становятся слабыми, вогда сопротивлевіе противъ пассивныхт двњженій еще сохранено. Это же явленіе она наблюдала у всьхъ, видынвыхъ ею больныхъ дрожательнымь шаралвчемь

A. III.

Dr Kurt Mendel. Травма въ этіологіи нервныхъ больвней. Der Unfall in der Aetiologie der Nervenkrankheiten.-Monatsschrift für Psychiatrie und Neurologie. Сентябрь 1907 Г.--іюнь I 908 г.

Печатавшаяся въ 10 книжкахъ журнала объемистая работа о роли травмы въ нервной патологі⿰, обосновава на тщательномь қритическомь изученіи огромнаго числа случаев' всевозможныхъ формь нервныхт больвней. 